\title{
Fish assemblages in three fringed mangrove bays of Santa Cruz Island, Galapagos Marine Reserve
}

\author{
Yasmania Llerena-Martillo ${ }^{1}$, César Peñaherrera-Palma ${ }^{2,3,4}$ \& Eduardo R. Espinoza ${ }^{4}$ \\ 1. San Francisco of Quito University - Galapagos Institute for the Arts and Sciences (GAIAS), Charles Darwin St., San \\ Cristobal Island, Ecuador; yasmania.1lerena@gmail.com \\ 2. Pontifical Catholic University of Ecuador - Manabí, Eudoro Loor St. Portoviejo, Manabí, Ecuador. \\ 3. Institute for Marine and Antarctic Studies, University of Tasmania, Private Bag 49, Hobart, TAS, Australia; \\ Cesar.Penaherrera@utas.edu.au \\ 4. Marines Ecosystems Monitoring, Galapagos National Park Directorate, Charles Darwin St., Santa Cruz Island, \\ Ecuador; eespinoza@galapagos.gob.ec
}

Received 22-VIII-2017. C Corrected 19-I-2018. Accepted 12-II-2018.

\begin{abstract}
Mangrove-fringed bays are highly variable ecosystems that provide critical habitats for fish species. In this study we assessed the fish assemblage in three mangrove-fringed bays (Punta Rocafuerte, Saca Calzón and Garrapatero) in the Southeast side of Santa Cruz Island, Galapagos Marine Reserve. Using gillnets, we carried out a total of 108 fieldtrips from January 2010 to December 2011. A total of 1773 bony and 740 cartilaginous fishes belonging to 26 species and 15 families were identified at the same sampling sites. Species richness was higher in the protected bay (Garrapatero) than in those open to fishing (Punta Rocafuerte, Saca Calzón). Blacktip sharks (Carcharhinus limbatus, $\mathrm{n}=729$ ), Thoburn's mullets (Mugil thoburni, $\mathrm{n}=492$ ), Peruvian mojarras (Diapterus peruvianus, $\mathrm{n}=440$ ), milkfish (Chanos chanos, $\mathrm{n}=206$ ) and the yellow fin mojarras (Gerres cinereus, $\mathrm{n}=197$ ) were the most common species across sites and season (cold and warm). The abundance of the most common species varied seasonally, with $C$. limbatus and C. chanos being more abundant in the warm season (December to April), and M. thoburni, C. limbatus and G. cinereus in the cold season (June to October). Temperature was the most important driver of abundance in $C$. limbatus and C. chanos, while salinity influenced Umbrina galapagorum. This study represents the first evaluation of the fish assemblage composition and dynamics in mangrove-fringed bays in the Galapagos Marine Reserve. Rev. Biol. Trop. 66(2): 674-687. Epub 2018 June 01.
\end{abstract}

Key words: fisheries; gill net; mangrove bays; marine ecology; environmental factors; Galapagos.

Mangrove ecosystems play a critical role in the ecology of many tropical fish species of high economic and ecological importance (Wolff, 2009). Mangrove tree roots create complex microhabitats which host a great diversity of marine wildlife (Beck et al., 2001), which subsequently foster the fish diversity found in neighboring marine ecosystems (Mumby et al., 2004). Birds, fish and crustaceans use mangrove bays particularly as nesting (Grant \& Grant, 1997), nursery (Laegdsgaard \& Johnson, 1995; Garnett, 2013), refuge (Bell, Pollard, Burchmore, Pease, \& Middleton, 1984) and feeding (Blaber, 2000; Heupel \& Hueter, 2002) grounds. This is due to the regular absence of large predatory species (Robertson \& Duke, 1987), the complex habitat structure (Nagelkerken \& van der Velde, 2002) and shadowing effect (Verweij et al., 2006) offered by mangrove fringed bays.

Mangroves are characterized by highly variable physical conditions (e.g. temperature, salinity and turbidity) (Gelin \& Gravez, 2002; Wolff, 2009), and high primary and secondary productivity (Wolff, 2009). Environmental factors play a critical role in the biodiversity and ecological function of mangrove ecosystems (Ashton, Macintosh, \& Hogarth, 2003). For 
example, salinity, turbidity and water temperature can influence the structure of juvenile fish assemblages (Whitfield, 1994; Blaber, 2000) in mangroves, costal lagoons, estuaries, and coastal areas (Blaber, 2000). Seasonal shifts in weather and oceanographic conditions can highly influence these and other environmental factors, particularly in areas where there are markedly dry and rainy seasons within one year (Barnes, 1980).

In the Galapagos Marine Reserve (GMR), mangrove trees grow over lava rocks in protected bays and occasionally behind sandy beaches around seawater lagoons, particularly in the islands located in the south-central region (Vinueza \& Flores, 2002). Mangrove bays were regarded as one of the main fishing grounds for fishermen in the GMR (Reck, 1983). Using gillnets made of nylon monofilament, artisanal fishermen mostly visit these areas during the warm season (December to April) to catch mullets (Mugil cephalus, Mugil thoburni), herrings (Ophistonema berlangai) and salemas (Xenichthys agassizii, Xenocys jessiae) (Peñaherrera-Palma, 2007). These fish species are used to supply the local market demand on salted and dry fish for Easter celebrations (Molina, Danulat, Oviedo, \& Gonzalez, 2004).

Although mangrove bays are known to provide refuge and protection to several commercial and iconic fishes (Llerena et al., 2015), their aquatic fauna in the GMR has been poorly evaluated. For example, earlier research efforts reported the presence of blacktip sharks (C. limbatus), mullets (Mugil cephalus) and milkfish (Chanos chanos) in coastal lagoons but without giving details on the species' abundance dynamics (Gelin \& Gravez, 2002; Llerena, 2009; Jaenig, 2010). A later study by Vaca (2010); Suárez (2012) and Garnett (2013) expanded the knowledge on the abundance of the fish fauna and flora in mangroves bays in the central area of the GMR. The latest research efforts have evaluated the incidence of fish in artisanal-fishing gillnets, with particular emphasis on the abundance of juvenile shark (Llerena et al., 2015). They sampled 34 bays around the GMR and identified at least nine nursery grounds for the blacktip shark $(C$. limbatus). This assessment provided important insights on the dynamics of juvenile blacktip sharks; yet they did not provide further information of the fish assemblage inhabiting these areas nor in relation to the environmental parameters influencing their dynamics.

The present study aimed at evaluating the fish assemblage's dynamics in mangrove-fringed bays in the GMR. Particularly, this study used experimental fishing in three mangrovefringed bays to 1) assess the fish community structure; 2) determine the seasonal and spatial variations in fish assemblages; and 3) evaluate the influence of the oceanographic and weather conditions on fish assemblages.

\section{MATERIALS AND METHODS}

Study site: The GMR is located in the Pacific Ocean $1000 \mathrm{~km}$ west from mainland Ecuador. The archipelago comprises of approximately 19 islands and 40 islets (Jackson, 1994). Marine management only allows the operation of artisanal fishing within the GMR, and in explicitly designated areas (Danulat \& Edgar, 2002). The main study sites were located in the Southeastern face of Santa Cruz Island, a volcanic island located in the center of the Galapagos Archipelago. The island covers an area of $985.22 \mathrm{~km}^{2}$ and has a coastline of $184 \mathrm{~km}$ length (DPNG, 2014). The sea surface temperature at Santa Cruz Island has been stable but with slight increased seasonality reported during the last four decades (Wolff, 2010). Seasonal temperatures during the warm months (December to April) average at 25.1 ${ }^{\circ} \mathrm{C}$, while cooler months (August-October) averaged at $21.8{ }^{\circ} \mathrm{C}$ (Wolff, 2010). Three sites located in the south-east face of the island were sampled: Punta Rocafuerte (RF; 0³9'35.15'S \& 90 $11^{\prime} 9.53^{\prime \prime} \mathrm{W}$ ) and Saca Calzón (SC; $0^{\circ} 41^{\prime} 5.57^{\prime \prime} \mathrm{S} \& 90^{\circ} 11^{\prime} 44.24$ ' W), where fishing is allowed; and, Garrapatero (GP; $0^{\circ} 42^{\prime} 4.25^{\prime \prime} \mathrm{S}$ \& 90 $0^{\circ} 13^{\prime} 20.74$ 'W), where fishing is prohibited (Fig. 1). The red mangrove (Rhizophora mangle) is the main plant species covering the bays 


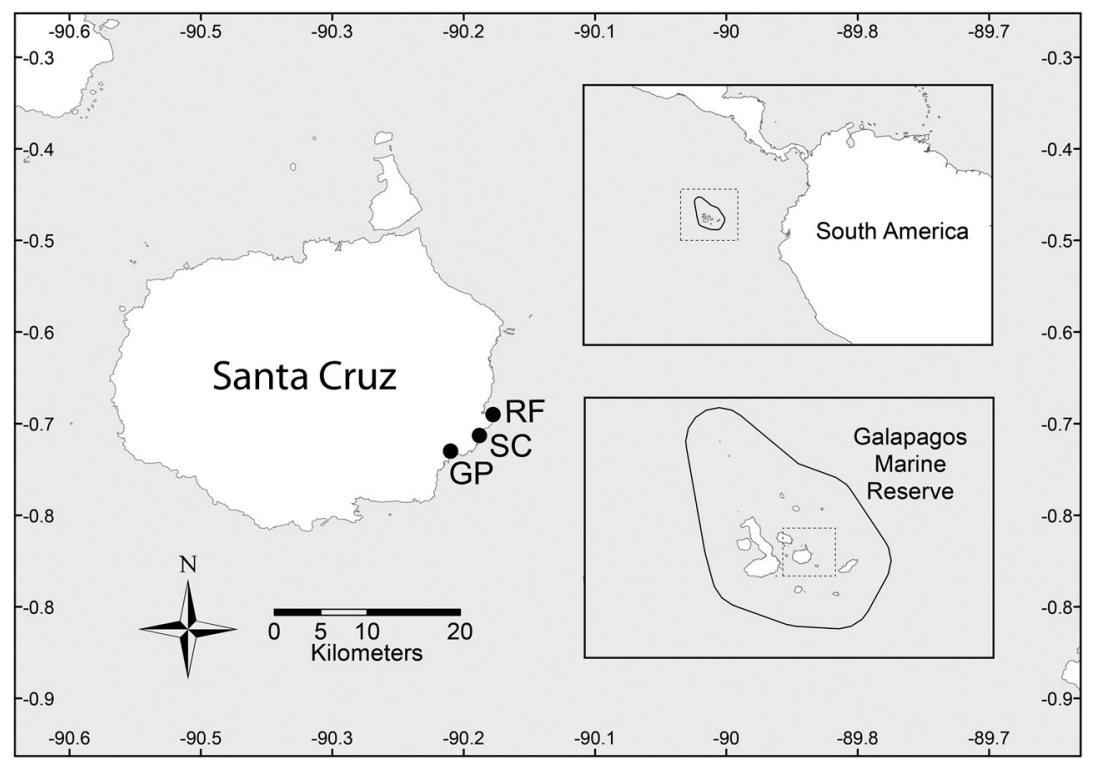

Fig. 1. Location of the main study sites: Punta Rocafuerte (RF), Saca Calzón (SC) and Garrapatero (GP).

across the Galapagos Archipelago (Danulat \& Edgar, 2002).

Data collection: Data was collected monthly between 2010 and 2011. Gill nets $100 \mathrm{~m}$ long, $3 \mathrm{~m}$ high and $7.6 \mathrm{~cm}$ mesh size were used during our sampling trips. These specifications were selected to match the fishing gear specifications used by artisanal fishermen (Peñaherrera-Palma, 2007) and to allow further assessment of the fishing gear effect on mangrove-fringed bays. Gill nets were deployed from 8:00 to 15:00 for one hour at the entrance of each bay using a small fiberglass vessel. Gill nets were regularly monitored to avoid mortality of the fishes caught by the nets. Once an individual was caught, it was brought on board to record its species and morphometric data (length, weight, sex). In the case of sharks, the presence of the umbilical scar was also checked to determine their maturity state: neonate (umbilical scar open), juvenile of the year (partially closed), and juvenile (umbilical scar absent). To identify the fish species caught during our sampling trips, we took pictures of the specimens and used the identification guides of Grove and Lavenberg (1997) and Molina et. al (2004). Field species identification was later corroborated with McCosker and Rosenblatt (2010) and Eschmeyer, Fricke, and van der Laan (2017). We followed the Directorate of the Galapagos National Park Protocols for handling marine life in mangrove bays (Llerena, Espinoza, \& Peñaherrera, 2011). No shark was handled for more than two minutes, and swimming was assisted during fish release back in the water if required.

We collected quantitative environmental variables (temperature, salinity, and depth) using a CTD (Conductivity, Temperature, Depth) at approximately two meters of depth. To assess the effect of moon phase on our sampling events we incorporated the moon luminosity as a quantitative variable in our dataset. Taking into account that new moon corresponds to $0 \%$ luminosity and full moon to $100 \%$ luminosity, we transformed our sampling date to the corresponding percentage of moonlight by calculating the number of days of our sampling date in relation to the previous full (or new) moon to the following new (or full) moon (Dewar et al., 2008). Precipitation 
(rainfall in mm) data from Puerto Ayora's meteorological station (located 18 kilometers from the study sites) was also used as an indirect measure of the rainfall metrics of the area (available at: www.darwinfoundation.org). We complemented these environmental factors with the categorical factors: time of the day (morning, midday, afternoon), season (warm, months from December to May; cold, June to November), and management (protected from fishing: Garrapatero; unprotected from fishing: Saca Calzón and Punta Rocafuerte).

Data analysis: We standardized our fishing effort and fish abundance by estimating the catch per unit effort (CPUE) as the number of individuals caught per $300 \mathrm{~m}^{2}$ of mesh per hour. To reduce the effect of dominant over rare species in our analysis we log-transformed the CPUE (also referred as abundance). We evaluated sampling effort with a Bootstrap (10000 randomizations) Species Richness analysis per site, following Clarke and Gorley (2006). To assess the species dominance per site and season, we calculated the actual species rank curve per year and plotted these results side by side. A species rank curve shows all the species organized in terms of the registered abundance (from high to low). A one-way Analysis of Similitude (ANOSIM) permutation test (Clarke \& Green, 1988) was used to test the effect of qualitative environmental factors over the sampled fish assemblage structure. Furthermore, we used the distance-based Redundancy Analysis (db-RDA) (Legendre \& Anderson, 1999) to explore the effect of the numerical quantitative variables over the fish abundance. Both ANOSIM and db-RDA analysis were calculated on the same Bray-Curtis similarity matrix. Multivariate analysis were carried out using the BiodiversityR Package (Kindt \& Coe, 2005) available in the R Statistical Software (R Core Team, 2016).

\section{RESULTS}

A total of 1773 bonefish and 740 cartilaginous fish corresponding to 26 species (24 bonefish and 2 cartilaginous) and 15 families were caught over 108 fieldtrips (Table 1). Haemulidae was the best-represented family with five species (Anisotremus interruptus, Haemulon sexfasciatum, Haemulon scudderii, Orthopristis lethopristis and Orthopristis sp.). We recorded 19 native and six endemic species (Opisthonema berlangai, Mugil cephalus, Umbrina galapagorum, Orthopristis lethopristis, Odontoscion eurymesops and Archosargus pourtalesii). Individual of one species was not identified to species level (Orthopristis sp.). We caught nine species of high commercial value for the artisanal fishing sector (Haemulon scudderii, Chanos chanos, Diapterus peruvianus, Mugil thoburni, Mugil cephalus, Lutjanus novemfasciatus, Lutjanus argentiventris, Scomberomorus sierra and Carax caninus); and one species of medium commercial value (Centropumus viridis).

The total fish abundance per site was highly variable, yet we did not observe any significant difference between sites (pairwise $t$-test $\mathrm{p}>0.05$; Fig. 2). Only one month (February 2010) showed an outstanding total abundance due to the presence of more individuals of blacktip sharks (C. limbatus). The cumulative species richness curve stabilized over ten species in the fishing grounds (Punta Rocafuerte and Saca Calzón), and over 15 species in the protected site (Garrapatero) (Fig. 2).

The blacktip shark (C. limbatus) was the most abundant species in all the study $(\mathrm{n}=729)$; followed by the Thoburn's mullet (M. thoburni; $\mathrm{n}=492)$; the peruvian mojarra (D. peruvianus; $\mathrm{n}=440$ ); the milkfish (C. chanos; $\mathrm{n}=206$ ); the yellow fin mojarra ( $G$. cinereus; $\mathrm{n}=197$ ) and the Galapagos mullet (M. cephalus; $\mathrm{n}=$ 112). These species were consistently recorded across sites and seasons (Fig. 3). In all except one site, $M$. thoburni and $C$. limbatus were the most important species. We found no clear pattern in the abundance variation between sites. In contrast, we observed a higher abundance of $C$. limbatus and $C$. chanos during the warm season, and of M. thoburni, C. limbatus and $G$. cinereus during the cold season. 
TABLE 1

Registered species and their taxonomic classification, presence within the sample sites, distribution range and fishing importance

\begin{tabular}{|c|c|c|c|c|c|c|c|}
\hline \multirow{2}{*}{ Species } & \multirow{2}{*}{ English name } & \multirow{2}{*}{$\begin{array}{l}\text { Species } \\
\text { Abbrev. }\end{array}$} & \multicolumn{3}{|c|}{ Study sites } & \multirow{2}{*}{$\begin{array}{l}\text { Distribution } \\
\text { range }\end{array}$} & \multirow{2}{*}{$\begin{array}{l}\text { Commercia } \\
\text { importance }\end{array}$} \\
\hline & & & PR & $\mathrm{SC}$ & GP & & \\
\hline \multicolumn{8}{|l|}{ Belonidae } \\
\hline Tylosurus pacificus & Pacific aguajon needlefish & Tylpac & $\mathrm{x}$ & & & Native & Low \\
\hline \multicolumn{8}{|l|}{ Carangidae } \\
\hline Caranx caninus & Pacific crevalle jack & Carcan & & & $\mathrm{x}$ & Native & High \\
\hline Oligoplites saurus & Leatherjacket & Olisau & & & $\mathrm{x}$ & Native & Low \\
\hline \multicolumn{8}{|l|}{ Carcharhinidae } \\
\hline Carcharhinus limbatus & Blacktip shark & Carlim & $\mathrm{x}$ & $\mathrm{x}$ & $\mathrm{x}$ & Native & None* \\
\hline \multicolumn{8}{|l|}{ Scaridae } \\
\hline Scarus ghobban & Blue-barred parrotfish & Scagho & & & $\mathrm{x}$ & Native & Low \\
\hline \multicolumn{8}{|l|}{ Centropomidae } \\
\hline Centropomus viridis & White snook & Cenvir & $\mathrm{x}$ & & & Native & Medium \\
\hline \multicolumn{8}{|l|}{ Chanidae } \\
\hline Chanos chanos & Milkfish & Chacha & $\mathrm{x}$ & $\mathrm{x}$ & $\mathrm{x}$ & Native & High \\
\hline \multicolumn{8}{|l|}{ Clupeide } \\
\hline Opisthonema berlangai & Galapagos thread herring & Opiber & $\mathrm{x}$ & $\mathrm{x}$ & $\mathrm{x}$ & Endemic & Low \\
\hline \multicolumn{8}{|l|}{ Gerriidae } \\
\hline Diapterus peruvianus & Peruvian mojarra & Diaper & $\mathrm{x}$ & $\mathrm{x}$ & $\mathrm{x}$ & Native & High \\
\hline Gerres cinereus & Yellow fin mojarra & Gercin & $\mathrm{x}$ & $\mathrm{x}$ & $\mathrm{x}$ & Native & Low \\
\hline \multicolumn{8}{|l|}{ Haemulidae } \\
\hline Anisotremus interruptus & Burrito grunt & Aniint & $\mathrm{x}$ & & $\mathrm{x}$ & Native & Low \\
\hline Haemulon sexfasciatum & Greybar grunt & Haesex & $\mathrm{x}$ & & & Native & Low \\
\hline Haemulon scudderii & Grey grunt & Haescu & $\mathrm{x}$ & $\mathrm{x}$ & $\mathrm{x}$ & Native & High \\
\hline Orthopristis lethopristis & Scalyfin grunt & Ortlet & $\mathrm{x}$ & $\mathrm{x}$ & & Endemic & Low \\
\hline Orthopristis sp. & Grunt sp. & Ortsp & $\mathrm{x}$ & $\mathrm{x}$ & $\mathrm{x}$ & Unknown & Low \\
\hline \multicolumn{8}{|l|}{ Kyphosidae } \\
\hline Kyphosus elegans & Cortez sea chub & Kypele & & & $\mathrm{x}$ & Native & Low \\
\hline \multicolumn{8}{|l|}{ Lutjanidae } \\
\hline Lutjanus novemfasciatus & Pacific dog snapper & Lutnov & & $\mathrm{x}$ & $\mathrm{x}$ & Native & High \\
\hline Lutjanus argentiventris & Yellow snapper & Lutarg & & & $\mathrm{x}$ & Native & High \\
\hline \multicolumn{8}{|l|}{ Mugilidae } \\
\hline Mugil thoburni & Thoburn's mullet & Mugtho & $\mathrm{x}$ & $\mathrm{x}$ & $\mathrm{x}$ & Native & High \\
\hline Mugil cephalus & Galapagos mullet & Mugcep & $\mathrm{x}$ & $\mathrm{x}$ & $\mathrm{x}$ & Endemic & High \\
\hline \multicolumn{8}{|l|}{ Sciaenidae } \\
\hline Umbrina galapagorum & Galapagos drum & Umbgal & $\mathrm{x}$ & $\mathrm{x}$ & $\mathrm{x}$ & Endemic & Low \\
\hline Corvula macrops & Vacuocua drum & Cormac & & & $\mathrm{x}$ & Native & Low \\
\hline Odontoscion eurymesops & Galapagos croaker & Odoeur & & & $\mathrm{x}$ & Endemic & Low \\
\hline \multicolumn{8}{|l|}{ Scombridae } \\
\hline Scomberomorus sierra & Pacific sierra & Scosie & & $\mathrm{x}$ & $\mathrm{x}$ & Native & High \\
\hline \multicolumn{8}{|l|}{ Sphyrnidae } \\
\hline Sphyrna lewini & Hammerhead shark & Sphlew & $\mathrm{x}$ & $\mathrm{x}$ & $\mathrm{x}$ & Native & None* \\
\hline \multicolumn{8}{|l|}{ Sparidae } \\
\hline Archosargus pourtalesii & Galapagos seabream & Arcrpou & $\mathrm{x}$ & $\mathrm{x}$ & $\mathrm{x}$ & Endemic & Low \\
\hline
\end{tabular}



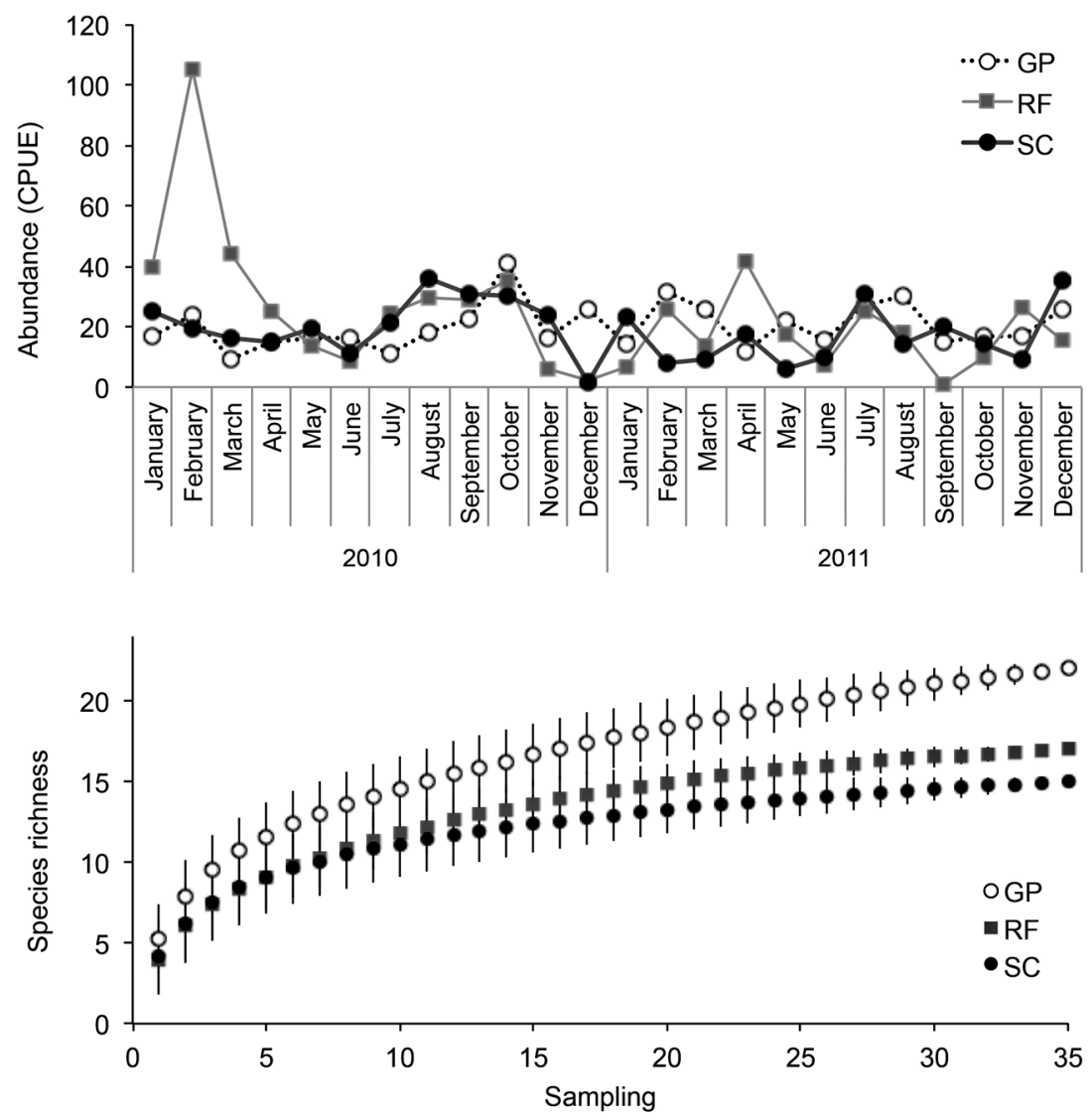

Fig. 2. Above: Monthly variation in the total fish abundance (CPUE) registered at the three study sites. Below: Cumulative species richness curve per site. Punta Rocafuerte (RF) and Saca Calzón (SC) were fishing grounds, and Garrapatero (GP) was protected from fishing.

We found no significant differences in the similitude between samplings of any of the assessed factors (Table 2). Although the degrees of correlation were rather weak $(\mathrm{R}=$ 0.08-0.02), we found significant differences in the fish assemblage between seasons and sites $(p<0.01)$. Management and time of the day did not yield any significant differences between samples $(p>0.05)$.

Environmental variables showed certain level of variation between sites and seasons, yet differences were not always significant (Table 3). Sea temperature was remarkably similar between the three study sites (mean range $24.9-25.2{ }^{\circ} \mathrm{C}$; $t$-test $p>0.54$ ), yet it was only significantly different between the cold (mean $22.5^{\circ} \mathrm{C}$ ) and the warm (mean $27.5^{\circ} \mathrm{C}$ ) seasons ( $t$-test $p<0.001)$. Higher salinity concentration values were recorded at Punta Rocafuerte (RF, $34.1 \mathrm{ppt})$ and during the warm season ( $\max 35.6 \mathrm{ppt}$ ), yet there were no significant differences between both sites and seasons ( $t$-test $p>0.09)$. Sampling depth varied between 1 to $3.4 \mathrm{~m}$, and it was the only variable that significantly differed between both sites and seasons ( $t$-test $p<0.04)$. The collection nature of both precipitation and moonlight only allowed seasonal comparisons, which resulted in significant differences for the former $(t$-test $p$ $<0.001)$, yet not significant for the latter ( $t$-test $p=0.528)$. 

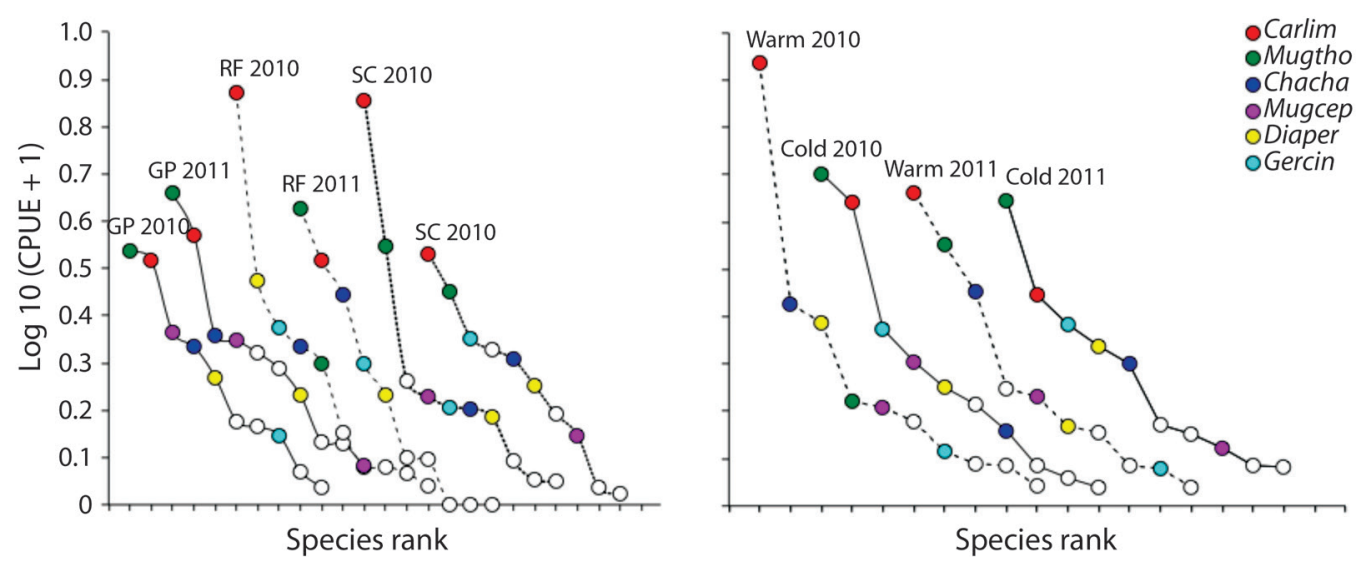

Fig. 3. Species rank of the six more important species per site (left) and season (right). Carlim = Carcharhinus limbatus; Mugtho = Mugil thoburni; Chacha = Chanos chanos; Muggal = Mugil cephalus; Gerper $=$ Diapterus peruvianus; Mugcin $=$ Gerres cinereus.

TABLE 2

ANOSIM results for the assessed factors

\begin{tabular}{llcc}
\multicolumn{1}{c}{ Factors } & \multicolumn{1}{c}{ Description } & R & $p$ \\
Season & Warm, cold. & 0.208 & 0.001 \\
Site & GP, RF, SC. & 0.072 & 0.001 \\
Management & Fishing, protected. & 0.073 & 0.015 \\
Time of day & Morning, midday, afternoon. & 0.023 & 0.693 \\
\hline
\end{tabular}

The accumulated constrained eigenvalues of the db-RDA reached up to $80 \%$ in the first two axes, implying an adequate representation of our constrained model (Fig. 4). The length of the environmental vectors of db-RDA suggests temperature and depth are major drivers of fish abundance in our study. C. limbatus and $C$. chanos occurred in higher abundance whenever the water temperature was higher (warmer). Differently, M. thoburni was inversely affected by water temperature, with more abundance occurring when the recorded temperature was the lowest. Salinity influenced the abundance of $U$. galapagorum but had little effect on the overall fish assemblage. Depth and precipitation had no positive effect in the abundance of any species, yet a weak negative effect on $G$. cinereus can be depicted in the ordination plot. While the effect of moonlight appears to have directly and positively influenced the abundance of Sphyrna lewini, the lack of overall captures did not show a strong correlation between these two. M. cephalus was indirectly affected by moonlight, suggesting a greater abundance of this species during or near new moon days.

\section{DISCUSSION}

The evaluation of the structure of fish assemblages and the environmental factors driving their dynamics are important steps to monitor the overall health of an ecosystem (Ecoutin, Richard, Simier, \& Albaret, 2005). By using experimental gillnet fishing, we sampled and monitored three mangrove-fringed bays in southeast Santa Cruz Island, Galapagos over two years. While we observed a relatively constant fish assemblage composition across sites and seasons, our analyses depicted spatial and seasonal differences at the species 
TABLE 3

Summary statistics of the measured temperature (Temp, $\left.{ }^{\circ} \mathrm{C}\right)$, salinity (Sal, ppm), Precipitation (Precip, mm), Depth (m), and MnLght (\%) between sites and seasons

\begin{tabular}{|c|c|c|c|c|c|}
\hline & Temp & Sal & Precip & Depth & MnLght \\
\hline \multicolumn{6}{|c|}{ Punta Rocafuerte } \\
\hline MEAN & 24.9 & 34.1 & 38.2 & 1.9 & 50.2 \\
\hline s.d. & 3.0 & 0.7 & 61.2 & 0.5 & 32.2 \\
\hline MIN & 21.3 & 32.1 & 0.8 & 1.0 & 0.0 \\
\hline MAX & 30.6 & 35.6 & 265.8 & 2.5 & 100.0 \\
\hline \multicolumn{6}{|l|}{ Saca Calzón } \\
\hline MEAN & 25.0 & 34.0 & 38.2 & 2.6 & 50.2 \\
\hline s.d. & 2.7 & 0.7 & 61.2 & 0.5 & 32.2 \\
\hline MIN & 20.9 & 32.1 & 0.8 & 1.3 & 0.0 \\
\hline MAX & 29.2 & 35.4 & 265.8 & 3.4 & 100.0 \\
\hline \multicolumn{6}{|l|}{ Garrapatero } \\
\hline MEAN & 25.2 & 33.8 & 38.2 & 2.2 & 50.2 \\
\hline s.d. & 2.7 & 0.6 & 61.2 & 0.6 & 32.2 \\
\hline MIN & 21.6 & 32.0 & 0.8 & 1.2 & 0.0 \\
\hline MAX & 29.4 & 35.2 & 265.8 & 3.4 & 100.0 \\
\hline \multicolumn{6}{|c|}{ Global Warm } \\
\hline MEAN & 27.5 & 34.0 & 70.6 & 2.4 & 54.3 \\
\hline s.d. & 1.4 & 0.8 & 72.5 & 0.6 & 35.3 \\
\hline MIN & 24.0 & 32.0 & 2.4 & 1.3 & 0.0 \\
\hline MAX & 30.6 & 35.6 & 265.8 & 3.4 & 100.0 \\
\hline \multicolumn{6}{|l|}{ Global Cold } \\
\hline MEAN & 22.5 & 34.0 & 5.9 & 2.1 & 46.1 \\
\hline s.d. & 1.0 & 0.5 & 4.6 & 0.5 & 27.7 \\
\hline MIN & 20.9 & 32.7 & 0.8 & 1.0 & 6.3 \\
\hline MAX & 25.2 & 34.8 & 18.6 & 3.0 & 92.9 \\
\hline
\end{tabular}

abundance level. Blacktip shark (C. limbatus) and thoburn's mullets (M. thoburni) were the most abundant species in this study, accounting for $30 \%$ and $20 \%$ of the total catch composition, respectively. Sea temperature was the single most important environmental factor driving the species abundance variation, particularly of blacktip sharks (positively) and thoburn's mullets (negatively). The implications of these results and their relevance for the management of the GMR are discussed below.

Indo-pacific tropical mangrove bays are considered to held larger species richness than other tropical mangroves of the world (Robertson \& Alongi, 1992). We registered a total of 26 fish species during our two-year survey, a species richness notably lower than other studies in estuarine bays of continental (e.g. Robertson \& Duke, 1987; Barletta-Bergan, Barletta, \& Saint-Paul, 2002) and island mangrove ecosystems (e.g. Blaber \& Milton, 1990; Gratwicke \& Speight, 2005). These differences are arguably a result of the survey methods used by each research. For example, by using nets of $0.1 \mathrm{~cm}$ mesh size, Barletta-Bergan et al. (2002) registered 25 fish families and 54 species in estuarine mangrove bays off the northern coast of Brazil. We collected 15 fish families and 26 species by using $7.6 \mathrm{~cm}$ meshsized gillnets. This fishing gear is highly selective to a fish size spectra of 30 to $70 \mathrm{~cm}$ in total length (Hamley, 1975), reducing the potential for collecting smaller and larger fish individuals as in Barletta-Bergan et al. (2002) study. 


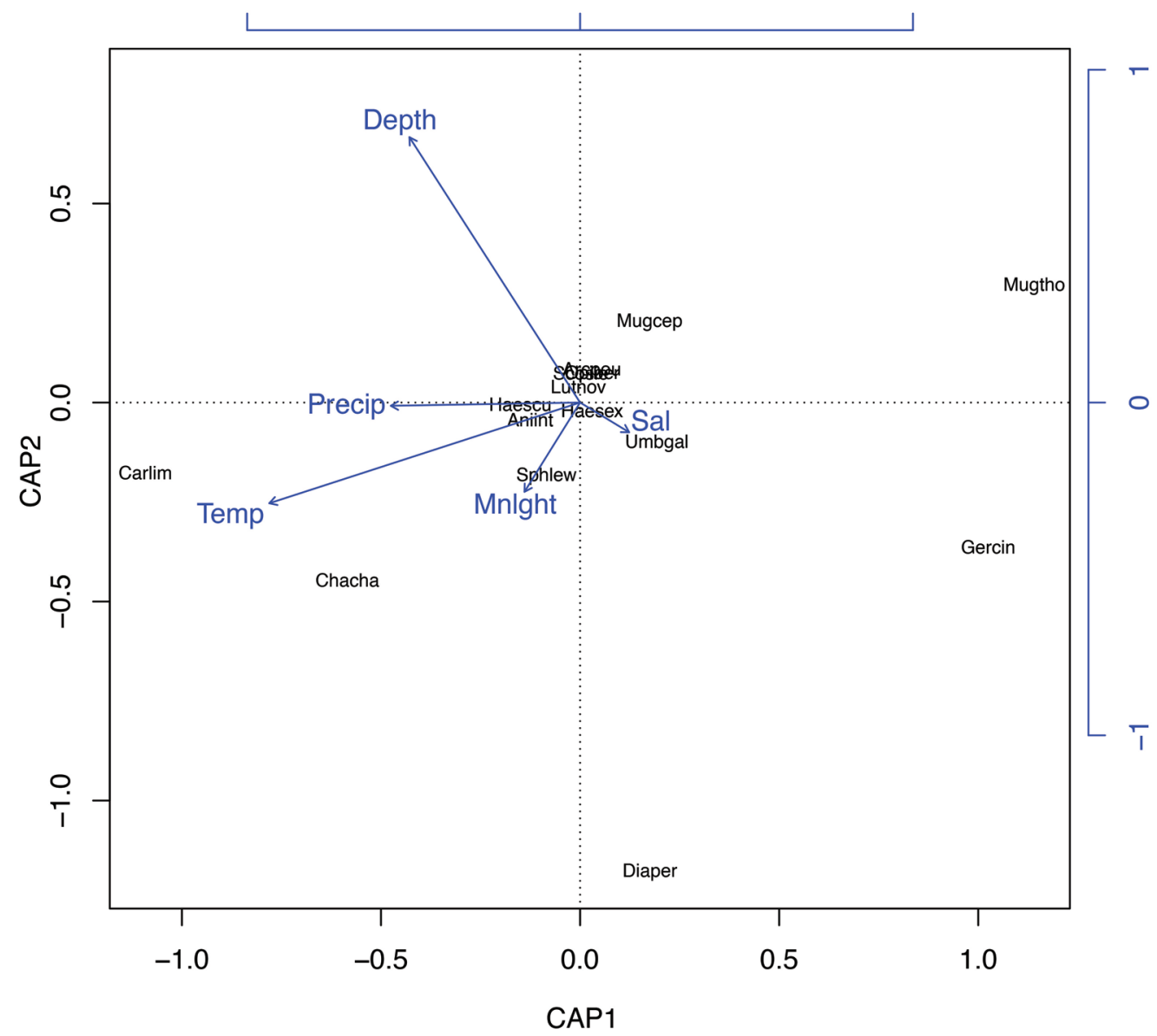

Fig. 4. Db-RDA ordination graph for the first two axes for the RF-SC-GP combined dataset using scaling method 1, the Bray-Curtis distance (blue), and temperature (Temp), salinity (Sal), depth, precipitation (Precip) and moonlight (MnLght) as constraining variables.

Our results are yet similar to other studies in nearby areas of the south-central GMR region. Llerena (2009) and Jaenig (2010) reported a total of 26 and 21 fish species, respectively, while sampling mangrove-fringed bays (in Southeast San Cristobal and Northwest Santa Cruz Islands) using identical fishing gears to our study. Furthermore, our study registered 12 species more than a previous five-year monitoring program on the gillnet fisheries operating in Galapagos (Peñaherrera-Palma, 2007). While our diversity may be relatively low due to the selectivity of the used fishing gear, the above-mentioned studies in Galapagos support our findings and suggest a higher diversity of medium size fish species sensitive to the gillnet operations in the GMR.

Fish distribution and abundance are known to be influenced by environmental and anthropogenic factors (e.g. Rojas, Pizarro, \& Castro, 1994; Heupel \& Hueter, 2002; Nagelkerken et al., 2008). With the exception of Garrapatero, fish assemblages were mostly constituted by the same species in our study and produced non-significant differences regardless of the management type and surveyed season. Observed significant differences were a product of differences in the seasonal abundance of the 
dominant fish species: Carcharhinus limbatus and Chanos chanos (more abundant in the warm season); and, M. thoburni, C. limbatus and $G$. cinereus (more abundant in the cold season). While we assessed several environmental variables, our findings suggest sea temperature as the single most important environmental variable driving the recorded fish abundance variation. In the case of $C$. limbatus, a positive correlation (higher abundance in warm temperatures) has been reported in mangrove bays in Florida's west coast (Heupel \& Hueter, 2002; Heupel, Carlson, \& Simpfendorfer, 2007), and Venezuela's Roques Archipelago (Tavares, 2008). We observed the same pattern in our study sites, with increased incidence of juvenile $C$. limbatus neonates during the warm season. Such abundance fluctuations have been linked to parturition habits of pregnant blacktip females seasonally using mangrove areas as pupping grounds (Heupel et al., 2007). Differently, the abundance of $M$. thoburni was negatively correlated to the increase in sea temperature during our study. Besides the description of its distribution along the Eastern Tropical Pacific ocean (Harrison, 1995), there is not much information on the thermal preferences of this or other mullet species. Andrade and Murillo (2002) reported a reduced contribution of mullets to the Galapagos artisanal fisheries landings during the 1997-1998 "El Niño" event (warm sea temperature conditions), yet increased contribution during 19981999 "La Niña" event (cold sea temperature conditions). Although these events were extreme oceanographic conditions, they provided insights into the thermal preferences of mullets in Galapagos and, to some extent, support to our findings. It is important to note that the allyear regular presence of the dominant species in these mangrove bays make it highly unlikely that $M$. thoburni and other fish species abundance is mediated by the presence of predatory C. limbatus. We nevertheless recommend a further in depth exploration of potential predatorprey interactions between the recorded sharks and bonny fish within this study.
Surprisingly, the effect of salinity on the overall fish assemblage was relatively low in our study. Salinity is reported to affect the structure and distribution (Peralta-Meixueiro \& Vega-Cendejas, 2011), as well as the metabolic processes (Nagelkerken et al., 2008) of juvenile fish species inhabiting estuarine mangrove environments. In such areas, the presence of freshwater streams can lower the salinity as low as close to 0 ppt (Froeschke, Stunz, \& Wildhaber, 2010). The lack of freshwater systems associated to mangrove bays in the GMR (Danulat \& Edgar, 2002) creates less variable salinity conditions (32-35 ppt) in comparison to estuarine ecosystems as the studies by Peralta-Meixueiro and Vega-Cendejas (2011) and Nagelkerken et al. (2008). The more homogeneous conditions found in our study sites could thus explain the lack of a major role of salinity in shaping the observed fish abundance.

Mangrove-fringed bays have traditionally been an important fishing ground for artisanal fishermen in the GMR (Murillo \& Bautil, 2002). Mullet species (M. thoburni and $M$. cephalus) are historically the most important target species of the artisanal gillnet fisheries operating in the GMR (IATTC, 1956; Reck, 1983). Only during the 1998-2006 period, these two species accounted for up to $30 \%$ of the total fish biomass landed in the GMR (Peñaherrera-Palma, 2007). Sustained fishing is known to reduce the overall ecosystem diversity (Hall, 1999), species density (Mangi \& Roberts, 2006), and growth traits of fish life history (Liang, Sun, Yan, Huang, \& Tang, 2013). Although we did not obtain significant differences between management types, the long-term fishing operation in these areas could be the underlining reason for the differences observed in species richness between the no fishing (Garrapatero) and fishing sites (Punta Rocafuerte and Saca Calzón). It is recommended to include other protected and unprotected mangrove bays into this assessment, and to evaluate any fishing impacts by removing the potential masking effect of more abundant species. For example, juvenile blacktip sharks are reported to actively move between mangrove 
bays (Heupel, Simpfendorfer, \& Hueter, 2003; Hirschfeld, 2013), which could be buffering their abundance in these areas and precluding any evidence on impacts at the assemblage level. Furthermore, our research shows juvenile blacktip sharks as the most abundant species in our study and suggests an unreported susceptibility of this species to the fishing gear used in these bays. Given the reserve wide protected status of shark species (SRP, 1989), the dynamics of blacktips in these areas should be further investigated to assess the level of impact it might be experiencing from artisanal gillnet fisheries.

The results of this study show our sampling sites are important habitats to native, endemic and protected fish species, in which population dynamics are mostly driven by thermal cues. Furthermore, our results show there is a higher number of species sensitive to artisanal gillnets than what was previously reported by the fishery's monitoring programs (PeñaherreraPalma, 2007). It is recommended a further evaluation of fisheries management strategies to avoid any ecological long-term impact on these bays, particularly over the endemic and protected species. While we did not assess the size spectra of the registered individuals, mangrove fringed bays represent an important refuge to juvenile individuals of almost all registered fish species (Grove \& Lavenberg, 1997). The value of preserving mangrove bays is high not only for managing commercial species, but to the nearby reef ecosystems were these species recruit to in later life stages (Mumby et al., 2004). It is also recommended that further revisions of management zoning schemes should include a wider amount of mangrove bays. Also, we recommend a closer revision of the effect of temperature on the fish assemblage's dynamics as a critical step to assess the impact of climate change in the resilience of these mangrove fish communities.

\section{ACKNOWLEDGMENTS}

The authors would like to thank to the Directorate of the Galapagos National Park, Conservation International, the Secretariat of Higher Education, Science, Technology and Innovation (formerly known as SENESCYT) of the Ecuadorean Government, Swen Lorenz, and the Charles Darwin Foundation for providing the necessary funding to carry out this research. We are particularly indebted to Carlos Bailón (Don Gabino) and Don Nelson, the crew of the Ranger patrolling boats, Elsa Freshet, Janai Yepez, and all the volunteers who helped during the project's fieldtrips.

\section{RESUMEN}

Ensamblaje de peces en tres bahías con bordes de manglar en la Isla Santa Cruz, Reserva Marina de Galápagos. Las bahías de manglar son ecosistemas muy variables que proveen hábitats críticos para especies de peces. En este estudio se evaluó los ensamblajes de peces de tres bahías de manglar (Punta Rocafuerte, Saca Calzón y Garrapatero) ubicadas en el sureste de la isla Santa Cruz, Reserva Marina de Galápagos. Usando redes de trasmallos iguales a los usados por la pesca artesanal, se llevaron a cabo un total de 108 salidas de campo entre enero 2010 y diciembre 2011. Un total 1773 peces óseos y 740 peces cartilaginosos correspondiendo a 26 especies y 15 familias fueron capturados, identificados y liberados con vida. La riqueza de especies fue mayor en Garrapatero (sitio protegido) que en Punta Rocafuerte y Saca Cazón (sitios abiertos a la pesca). Las mayores capturas estuvieron representadas por el tiburón punta negra (Carcharhinus limbatus; $\mathrm{n}=729$ ), seguido la lisa rabo negro (Mugil thoburni; $\mathrm{n}=492$ ), la mojarra peruana (Diapterus peruvianus; $\mathrm{n}=440$ ), la diabla (Chanos chanos; $\mathrm{n}=206$ ) y la mojarra rayada (Gerres cinereus; $\mathrm{n}=197$ ). A pesar que éstas especies fueron consistentemente las más importantes a través de los sitios y temporadas (caliente y fría), se observó una mayor abundancia de $C$. limbatus y $C$. chanos durante la temporada caliente (enero a abril), y de M. thoburni, $C$. limbatus y $G$. cinereus durante la temporada fría (junio a octubre). La temperatura fue determinada como el factor más importante que influye en la abundancia de C. limbatus y C. Chanos, mientras la salinidad lo fue para Umbrina galapagorum. Este estudio representa una importante contribución para el entendimiento de la composición de 
los ensamblajes de peces en las bahías de manglar de la Reserva Marina de Galápagos.

Palabras clave: pesquerías; red de enmalle; bahías de manglares; ecología marina; factores ambientales; Galápagos.

\section{REFERENCES}

Andrade, R., \& Murillo, J. C. (2002). Lisas. In E. Danulat \& G. J. Edgar (Eds.), Reserva Marina de Galápagos. Línea Base de la Biodiversidad (pp. 119-145). Puerto Ayora, Galápagos, Ecuador: Fundación Charles Darwin y Servicio Parque Nacional Galápagos.

Ashton, E. C., Macintosh, D. J., \& Hogarth, P. J. (2003). A baseline study of the diversity and community ecology of crab and molluscan macrofauna in the Sematan mangrove forest, Sarawak, Malaysia. Journal of Tropical Ecology, 19(02). doi: 10.1017/ s0266467403003158

Barletta-Bergan, A., Barletta, M., \& Saint-Paul, U. (2002). Community structure and temporal variability of ichthyoplankton in North Brazilian mangrove creeks. Journal of Fish Biology, 61(sa), 33-51. doi: 10.1111/ j.1095-8649.2002.tb01759.x

Barnes, R. S. K. (1980). Coastal Lagoons. Cambridge, UK: Cambridge University Press.

Beck, M. W., Heck, K. L., Able, K. W., Childers, D. L., Eggleston, D. B., Gillanders, B. M., . . . Weinstein, M. P. (2001). The Identification, Conservation, and Management of Estuarine and Marine Nurseries for Fish and Invertebrates. Bioscience, 51(8), 633. doi: 10.1641/0006-3568(2001)051[0633:ticamo]2.0.co;2

Bell, J., Pollard, D., Burchmore, J., Pease, B., \& Middleton, M. (1984). Structure of a fish community in a temperate tidal mangrove creek in Botany Bay, New South Wales. Australian Journal of Marine and Freshwater Research, 35, 33-46.

Blaber, S. J. M. (2000). Tropical estuarine fishes: ecology, exploitation and conservation. Oxford, UK: Blackwell.

Blaber, S. J. M., \& Milton, D. A. (1990). Species composition, community structure and zoogeography of fishes of mangrove estuaries in the Solomon Islands. Marine Biology, 105(2), 259-267. doi: 10.1007/ bf01344295

Clarke, K. R., \& Gorley, R. N. (2006). PRIMER v6: User manual/tutorial: PRIMER E. Plymouth.

Clarke, K. R., \& Green, R. H. (1988). Statistical design and analysis for a "biological effects" study. Marine Ecology Progress Series, 46, 213-226.

Danulat, E., \& Edgar, G. (2002). Reserva Marina de Galápagos. Linea Base de la Biodiversidad. Santa
Cruz, Galápagos, Ecuador: Fundación Charles Darwin y Parque Nacional Galápagos.

Dewar, H., Mous, P., Domeier, M., Muljadi, A., Pet, J., \& Whitty, J. (2008). Movements and site fidelity of the giant manta ray, Manta birostris, in the Komodo Marine Park, Indonesia. Marine Biology, 155, 121133. doi: DOI 10.1007/s00227-008-0988-x

DPNG (Dirección del Parque Nacional Galápagos). (2014). Plan de Manejo de las Áreas Protegidas de Galápagos para el Buen Vivir. Puerto Ayora, Galápagos, Ecuador.

Ecoutin, J. M., Richard, E., Simier, M., \& Albaret, J.-J. (2005). Spatial versus temporal patterns in fish assemblages on a tropical estuarine coastal lake: The Ebrié Lagoon (Ivory Coast). Estuarine Coastal and Shelf Science, 64, 623-635.

Eschmeyer, W. N., Fricke, R., \& van der Laan, R. (2017). Catalog of Fishes: Genera, species, references. Retrieved Electronic version accessed 10 July 2017, from California Academy of Sciences http:// researcharchive.calacademy.org/research/ichthyology/catalog/fishcatmain.asp

Froeschke, J., Stunz, G., \& Wildhaber, M. (2010). Environmental influences on the occurrence of coastal sharks in estuarine waters. Marine Ecology Progress Series, 407, 279-292. doi: 10.3354/meps08546

Garnett, E. (2013). Evaluating mangroves as essential nursery grounds for snapper (Lutjanidae) and grunts (Haemulidae) on southern Isabela, Galápagos Islands (Master's Thesis). Kiel University, Kiel, Germany.

Gelin, A., \& Gravez, V. (2002). Lagunas Costeras. In E. Danulat \& G. Edgar (Eds.), Reserva Marina de Galápagos. Línea Base de la Biodiversidad (pp. 119145). Santa Cruz, Galápagos, Ecuador: Fundación Charles Darwin/Servicio Parque Nacional Galápagos.

Grant, P. R., \& Grant, B. R. (1997). The rarest of Darwin's finches. Conservation Biology, 11(1), 119-126.

Gratwicke, B., \& Speight, M. R. (2005). The relationship between fish species richness, abundance and habitat complexity in a range of shallow tropical marine habitats. Journal of Fish Biology, 66, 650-667. doi: 10.1111/j.1095-8649.2005.00629.x

Grove, J. S., \& Lavenberg, R. J. (1997). The fishes of the Galápagos Islands. Stanford, California: Stanford Univerversity Press.

Hall, S. (1999). The effects of fishing on marine ecosystems and communities. Oxford, U.K.: Blackwell Science Ltd.

Hamley, J. M. (1975). Review of Gillnet Selectivity. Journal of the Fisheries Research Board of Canada, 32(11), 1943-1969. doi: 10.1139/f75-233 
Harrison, I. J. (1995). Mugilidae. Lisas. In W. Fischer, F. Krupp, W. Schneider, C. Sommer, C. K. E. \& V. Niem (Eds.), Guia FAO para Identification de Especies para lo Fines de la Pesca. Pacifico Centro-Oriental (Vol. 3, pp. 1293-1298). Rome, Italy: FAO.

Heupel, M. R., Carlson, J. K., \& Simpfendorfer, C. A. (2007). Shark nursery areas: concepts, definitions, characterization and assumptions. Marine Ecology Progress Series, 337, 287-297.

Heupel, M. R., \& Hueter, R. E. (2002). Importance of prey density in relation to the movement patterns of juvenile blacktip sharks (Carcharhinus limbatus) within a coastal nursery area. Marine Freshwater Research, $53,543-550$.

Heupel, M. R., Simpfendorfer, C. A., \& Hueter, R. E. (2003). Running before the storm: blacktip sharks respond to falling barometric pressure associated with Tropical Storm Gabrielle. Journal of Fish Biology, 63(5), 1357-1363. doi: 10.1046/j.1095-8649.2003.00250.x

Hirschfeld, M. (2013). Habitat use and movement patterns of juvenile and neonate blacktip sharks, Carcharhinus limbatus, in nursery areas on San Cristobal Island, Galapagos. Masther in University San Francisco de Quito, Quito, Ecuador.

IATTC (Inter American Tropical Tuna Comission). (1956). Annual Report of the year 1955. Inter American Tropical Tuna Comission: La Jolla, California.

Jackson, M. H. (1994). Galapagos: A Natural History, Revised and Expanded. Toronto, Canada: University of Calgary Press.

Jaenig, M. (2010). Sharks (Selachii) in mangrove-fringed habitats of the Galápagos Marine Reserve (GMR) with implications for management and conservation (Master's Thesis). University of Bremen, Bremen, Germany.

Kindt, R., \& Coe, R. (2005). Tree diversity analysis. A manual and software for common statistical methods for ecological and biodiversity studies. Nairobi, Kenya.: World Agroforestry Centre.

Laegdsgaard, P., \& Johnson, C. R. (1995). Mangrove habitats as nurseries: unique assemblages of juveniles fish in subtropical mangroves in eastern Australia. Marine Ecology Progress Series, 126, 67-81.

Legendre, P., \& Anderson, M. J. (1999). DistanceBased Redundancy Analysis: Testing Multispecies Responses in Multifactorial Ecological Experiments. Ecological Monographs, 69(1), 1-24. doi: 10.1890/0012-9615(1999)069[0001:dbratm]2.0 .co;2

Liang, Z., Sun, P., Yan, W., Huang, L., \& Tang, Y. (2013). Significant effects of fishing gear selectivity on fish life history. Journal of Ocean University of China, 13(3), 467-471. doi: 10.1007/s11802-014-2167-7
Llerena, Y. (2009). Identificación de tiburones juveniles y caracterización de sus hábitats en las zonas costeras de pesca de la isla San Cristóbal - Reserva Marina de Galápagos (Degree's Thesis). Universidad de Guayaquil, Guayaquil, Ecuador.

Llerena, Y., Espinoza, E., \& Peñaherrera, C. (2011). Manual para el monitoreo y marcaje en tiburones juveniles de las zonas de manglar de la Reserva Marina de Galápagos. Puerto Ayora, Galápagos, Ecuador: Dirección del Parque Nacional Galápagos y Fundación Charles Darwin.

Llerena, Y., Peñaherrera, C., Espinoza, E., Hirschfeld, M., Wolff, M., \& Vinueza, L. R. (2015). Nursery grounds of blacktip sharks (Carcharhinus limbatus) in mangrove-fringed bays in the central part of the Galapagos Archipelago. In L. J. Cayot, D. Cruz, \& R. Knab (Eds.), Galapagos Report 2013-2014: GNPD, GCREG, CDF and GC (pp. 102-110). Puerto Ayora, Galápagos, Ecuador.

Mangi, S. C., \& Roberts, C. M. (2006). Quantifying the environmental impacts of artisanal fishing gear on Kenya's coral reef ecosystems. Marine Pollution Bulletin, 52(12), 1646-1660. doi: 10.1016/j. marpolbul.2006.06.006

McCosker, J. E., \& Rosenblatt, R. H. (2010, September 15). The Fishes of the Galápagos Archipelago: An Update. Paper presented at the Proceedings of the California Academy of Sciences, California.

Molina, L., Danulat, E., Oviedo, M., \& Gonzalez, J. A. (2004). Guia de especies interés pesquero en la Reserva Marina de Galápagos. Puerto Ayora, Galápagos, Ecuador: Fundación Charles Darwin, Agencia Española de Cooperación Internacional y Dirección Parque Nacional Galápagos.

Mumby, P. J., Edwards, A. J., Arias-Gonzalez, J. E., Lindeman, K. C., Blackwell, P. G., Gall, A., . . . Llewellyn, G. (2004). Mangroves enhance the biomass of coral reef fish communities in the Caribbean. Nature, 427(6974), 533-536. doi: 10.1038/nature02286

Murillo, J. C., \& Bautil, B. (2002). Evaluación de las pesquerías en la Reserva Marina de Galápagos. Informe Compendio 2002 (pp. 124). Puerto Ayora, Galapagos, Ecuador: Servicio Parque Nacional Galapagos \& Fundacion Charles Darwin.

Nagelkerken, I., Blaber, S. J. M., Bouillon, S., Green, P., Haywood, M., Kirton, L. G., . . . Somerfield, P. J. (2008). The habitat function of mangroves for terrestrial and marine fauna: A review. Aquatic Botany, 89(2), 155-185. doi: 10.1016/j.aquabot.2007.12.007

Nagelkerken, I., \& van der Velde, G. (2002). Do nonestuarine mangroves harbour higher densities of juvenile fish than adjancent shallow water and coral reef habitats in Curaçao (Netherlands Antilles)? Marine Ecology Progress Series, 245, 191-204. 
Peñaherrera-Palma, C. (2007). Variaciones espacio-temporales de los ensambles de peces de la Reserva Marina de Galápagos basados en registros pesqueros (Bachelor Thesis). Pontificia Universidad Católica del Ecuador, Ecuador.

Peralta-Meixueiro, M. A., \& Vega-Cendejas, M. E. (2011). Evaluación espacio-temporal de los ensamblajes de peces en el sistema lagunar de Río Lagartos, México. Gulf and Caribbean Fisheries Institute, 63, 274-281.

R Core Team. (2016). R: A language and environment for statistical computing. Vienna, Austria: R Foundation for Statistical Computing.

Reck, G. K. (1983). The coastal fisheries in the Galápagos Islands, Ecuador. Description and consequences for management in the context of marine environmental protection and regional development (Doctoral Thesis). Kiel University, Kiel, Germany.

Robertson, A. I., \& Alongi, D. M. (1992). Tropical Mangrove Ecosystems. Washington, D.C., USA: American Geophysical Union.

Robertson, A. I., \& Duke, N. C. (1987). Mangroves as nursery sites: comparisons of the abundance and species composition of fish and crustaceans in mangroves and other nearshore habitats in tropical Australia. Marine Biology, 96, 193-205.

Rojas, J. R., Pizarro, J. F., \& Castro, M. (1994). Diversidad y abundancia íctica en tres áreas de manglar en el Golfo de Nicoya, Costa Rica. Revista de Biología Tropical, 42(3), 663-672. doi: http://dx.doi. org/10.15517/rbt.v42i3.23271

SRP (Subsecretaria de Recursos Pesqueros). (1989). Acuerdo Ministerial No. 151 (Vol. 151). Ministerio de Industrias, Ganadería y Pesca: Guayaquil, Ecuador.
Suárez, J. (2012). Comunidades biológicas en los manglares de Isabela, Santa Cruz y San Cristóbal (Degree's Thesis). Universidad de Guayaquil, Guayaquil, Ecuador.

Tavares, R. (2008). Occurrence, diet and growth of juvenile blacktip sharks, Carcharhinus limbatus, from los Roques Archipelago National Park, Venezuela. Caribbean Journal of Science, 44(3), 291-302.

Vaca, L. (2010). Diversidad de osteichthyes y condricthyes en tres ecosistemas marinos: manglar, arrecife coralino y rocoso de la zona submareal de la isla San Cristóbal (Degree's Thesis). Univerdidad de Guayaquil, Guayaquil, Ecuador.

Verweij, M. C., Nagelkerken, I., de Graaff, D., Peeters, M., Bakker, E. J., \& van der Velde, G. (2006). Structure, food and shade attract juvenile coral reef fish to mangrove and seagrass habitats: a field experiment. Marine Ecology Progress Series, 306, 257-268.

Vinueza, L. R., \& Flores, M. (2002). Comunidades intermareales rocosas. In E. Danulat \& G. J. Edgar (Eds.), La Reserva Marina de Galápagos. Línea Base de la Biodiversidad. (pp. 98-118). Santa Cruz, Galápagos, Ecuador: Fundación Charles Darwin / Parque Nacional Galápagos.

Whitfield, A. K. (1994). Abundance of larval and 0+ juvenile marine fishes in the lower reaches of three southern African esturies with differing freshwater inputs. Marine Ecology Progress Series, 105, 257-267.

Wolff, M. (2009). Tropical waters and their living resources: ecology, assessment and management. Bremen, Germany: Verlag H. M. Hauschild GmbH.

Wolff, M. (2010). Galapagos does not show recent warming but increased seasonality. Galapagos Research, $67,38-44$. 